\title{
TESTS OF A BALANCED THERMOCOUPLE AND FILTER RADIOMETER AS A STANDARD ULTRA-VIOLET DOSAGE INTENSITY METER
}

\author{
By W. W. Coblentz, R. Stair, and J. M. Hogue
}

\section{ABSTRACT}

Data are given on the accuracy of the balanced thermocouple and filter radiometer as a standard ultra-violet dosage intensity meter.

The erythema produced by the radiometrically measured amount of heterogeneous ultra-violet radiation is compared with that produced by a measured aniount of homogeneous radiation of the emission line of mercury, at $297 \mathrm{~m} \mu$, which is used as a standard.

This requires the determination of the ultra-violet spectral energy curve, and the total ultra-violet of wave lengths less than and including $313 \mathrm{~m} \mu$, of the source under test. An exact knowledge of the spectral erythemic response of the skin is also required ( $\mathrm{RP} 433$ ).

Sources differing markedly in ultra-violet spectral energy distribution were investigated, including as extremes the sun, and the so-called "cold quartz" mercury vapor lamp.

A close agreement was found between the physiologically and the radiometrically determined erythemogenic efficiency of all the sources examined, including the sun, the Mazda S-1 and S-2 lamps, the high temperature quartz mercury arc lamp, and the carbon arcs of "therapeutic B, C, and white flame," carbon electrodes.

A specification is given (a) of minimum intensity to insure effective therapeutic results, and (b) of the erythemogenic unit of dosage; both in terms of the emission line of mercury, at $297 \mathrm{~m} \mu$, as a standard.

On the basis that a minimum intensity of $20 \mu \mathrm{W} / \mathrm{cm}^{2}$ of homogeneous radiation of wave length $297 \mathrm{~m} \mu$ is desirable, the erythemogenic equivalent of heterogeneous ultra-violet radiation of wave lengths less than and including $313 \mathrm{~m} \mu$, in microwatts per square centimeter, is approximately as follows: The sun, 91; the Mazda S-1 lamp, 80; the Mazda S-2 lamp, 93; the high temperature quartz mercury arc, 58; the so-called "cold quartz" mercury vapor lamp, 36; and the therapeutic carbon arcs, 45 to $90 \mu W / \mathrm{cm}^{2}$.

For an erythemogenic unit of dosage, $10,000 \mathrm{ergs} / \mathrm{cm}^{2}$ of homogeneous radiation of the emission line of mercury at $297 \mathrm{~m} \mu(2,967 \mathrm{~A})$ is suggested.

\section{CONTENTS}

Page

760

I. Introduction

II. Experimental procedure

1. Determination of the ultra-violet spectral energy distribution of the heterogeneous source

2. Determination of the total ultra-violet radiant flux of wave lengths less than $313 \mathrm{~m} \mu$ in the heterogeneous source...-

3. Determination of the minimum perceptible erythema using homogeneous radiation

4. Determination of the minimum perceptible erythema produced by heterogeneous ultra-violet radiation._.....
761

762

763

764

768 
III. Comparison of ultra-violet intensities by radiometric and erythemal

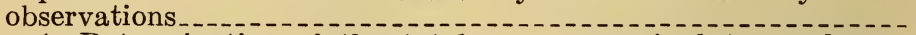

1. Determination of the total energy required to produce a minimum perceptible erythema using the standard line at $297 \mathrm{~m} \mu$

2. Determination of the total energy required to produce a minimum perceptible erythema using various sources of heterogeneous ultra-violet radiation..............

3. Erythemogenic efficiency of various sources of ultra-violet radiation - .

(a) The sun.

(b) The carbon arc lamp.

(c) The mercury arc lamp....................

IV. Specification of minimum intensity and the erythemogenic unit of dosage............

V. Bibliography

\section{INTRODUCTION}

During the past few years investigations have been in progress in this country and abroad, of various proposed methods of measuring the intensity, or so-called dosage of ultra-violet radiation of wave lengths less than about $315 \mathrm{~m} \mu$, which rays are found useful for thera. peutic purposes, particularly in the healing of rickets.

These various methods are photo-electric, photochemical, photo. graphic, and photometric. They are simple to operate; but the chief difficulty in their use is that they must be calibrated on an arbitrary basis, and there is no unchangeable source of ultra-violet radiation which can be used as a standard of comparison. This is exemplified in a recent investigation (1) ${ }^{1}$ during the culmination of which work, certain inconsistencies were found in the photo-electric measurements, which indicated a decrease in the intensity of the source (a quartz mercury arc lamp) used as a standard.

In the preliminary search for a primary standard dosage intensity meter, the writers have tried the isolation of the ultra-violet of wave lengths less than and including $313 \mathrm{~m} \mu$ in one wide band by means of a quartz spectrograph (4) supplemented by a barium flint glass filter, to correct for spectral impurities and scattered radiation of wave lengths longer than $313 \mathrm{~m} \mu$. This appeared to be the simplest means available for calibrating the photo-electric cell in absolute measure by comparison with a surface thermopile. However, in attempting to measure the ultra-violet in solar radiation, difficulties were experienced in maintaining the spectrum calibration and in isolating the ultra-violet at exactly $313 \mathrm{~m} \mu$, especially when using the spectropyrheliometer mounted upon a polar axis. Hence, this method of attack was discontinued, although it appeared sound in principle.

The purpose of the present communication is to show the reliability of the balanced thermocouple and filter radiometer as a dosage intensity meter, for measuring the ultra-violet radiation emitted by sources differing widely in spectral energy distribution, such as, for example, the so-called "cold quartz" mercury vapor arc in which over 95 per cent of the total radiation of wave lengths less than and including $313 \mathrm{~m} \mu$ is contained in the resonance emission line of mercury at

\footnotetext{
1 Figures in parentheses here and throughout the text indicate references given in the bibliography at the end of this paper.
} 
$254 \mathrm{~m} \mu$, and the sun which contains practically no radiation of wave lengths less than $290 \mathrm{~m} \mu$.

The estimation of the reliability of this device as a dosage meter is based upon a determination of the (observed and calculated) total energy required to produce a minimum perceptible erythema when exposure is made to measured amounts of heterogeneous radiation from different sources (evaluated by means of the balanced thermocouple and filter radiometer) as compared with the energy required to produce a minimum perceptible ery thema on exposure of the same part of the body to a measured amount of homogeneous radiation of wave length $297 \mathrm{~m} \mu$, which is used as a standard.

The erythema test was selected because this method is in common use as a guide in ultra-violet radiation therapy. Furthermore, in view of the wide variation in erythemic susceptibility of pigmented and unpigmented skin, and in view of the fact that exposure to ultraviolet radiation can not be continued safely beyond the tolerance of the skin, which is indicated by the erythema produced, it is highly probable that this physiological effect will always have to be taken into consideration.

It is to be emphasized that the present measurements pertain to the amount of ultra-violet radiation that can be safely applied to the skin without producing an excessive erythema. No attempt is made to determine whether any photochemical or healing effects may be produced.

It is to be noted that while the erythemogenic efficiency of some of these sources appears to be lower, the photochemical activation (for example, ergosterol) may, perhaps, be found higher than that of other sources of higher erythemogenic value. In other words, while the herein-recorded erythemogenic efficiency data serve as a useful guide in estimating the dosage applicable without producing an excessive ery thema, they do not necessarily serve as a guide in activating oils, foods, etc., and for healing purposes. This is especially true of ultraviolet radiation of wave lengths in the region of $250 \mathrm{~m} \mu$, which rays, according to several experimenters (6), are found to deactivate vitamin $\mathrm{D}$, and, hence, should not be used for producing this particular photochemical reaction.

\section{EXPERIMENTAL PROCEDURE}

Preliminary to the description of the experimental details, it is relevant to recall that the long wave length limit, used in making the calculations and comparisons, is taken at $313 \mathrm{~m} \mu(a)$ because erythemal and antirachitic activity practically ceases at this wave length and $(b)$ because the emission line of mercury at $313 \mathrm{~m} \mu$ is easily obtainable for radiometric measurements and as a limiting wave length in the mechanical isolation and integration of ultra-violet radiation of wave lengths less than and including $313 \mathrm{~m} \mu$.

Similarly the emission line of mercury at $297 \mathrm{~m} \mu$ is taken as a standard for erythemal and radiometric comparisons $(a)$ because it is close to the maximum of erythemic susceptibility, and $(b)$ because it is easily obtained as a source that is readily evaluated in absolute units by direct comparison with a standard of radiation of established constancy. In these comparisons the exit slit acts as the source and no consideration of absorption in the spectroradiometer or change in intensity with aging of the lamp is necessary. 
In order to obtain an accurate comparison between the physiological (erythemal) and the radiometric determinations of the ultraviolet intensity of a given source, it is necessary to obtain four important sets of data.

\section{DETERMINATION OF THE ULTRA-VIOLET SPECTRAL ENERGY DISTRIBUTION OF THE HETEROGENEOUS SOURCE}

The ultra-violet spectral energy distribution of the artificial sources was determined by means of a spectroradiometer, consisting of two uncemented quartz-fluorite achromatic lenses, $33 \mathrm{~mm}$ in diameter and $30 \mathrm{~cm}$ focal length, and a $60^{\circ}$ quartz prism, $6 \mathrm{~cm}$ in height. The radiometer consisted of a vacuum thermopile and an iron-clad Thomson galvanometer.

The reduction of the data from the prismatic to the normal spectrum (the slit width correction), and the corrections for absorption by the fluorite window and the spectrometer, are described on page 738 of the preceding paper (3); and they are indicated in Table 1. In view of the fact that only relative and not absolute values of spectral intensities are required, the reduction of the data is somewhat simpler than in the preceding paper.

TABLE 1.-Relative ultra-violet spectral intensities of a white flame carbon arc reduced to normal spectrum

\begin{tabular}{|c|c|c|c|c|c|}
\hline $\begin{array}{l}\text { Ob- } \\
\text { served } \\
\text { wave } \\
\text { length }\end{array}$ & $\begin{array}{l}\text { Galva- } \\
\text { nometer } \\
\text { deflec- } \\
\text { tion }\end{array}$ & $\begin{array}{l}\text { Spectrom- } \\
\text { oter trans- } \\
\text { mission } \\
\text { sion }\end{array}$ & $\begin{array}{l}\text { Slit width } \\
\text { correc- } \\
\text { tion }\end{array}$ & $\begin{array}{l}\text { Fluorite } \\
\text { window, } \\
\text { transmis- }\end{array}$ & $\begin{array}{c}\text { Relative } \\
\text { energy } \\
\frac{2}{3 \times 4 \times 5}\end{array}$ \\
\hline 1 & 2 & 3 & 4 & 5 & 6 \\
\hline $\begin{array}{c}m_{\mu} \\
440 \\
420 \\
403 \\
390 \\
378\end{array}$ & $\begin{array}{r}13.90 \\
13.17 \\
12.30 \\
11.90 \\
7.10\end{array}$ & $\begin{array}{l}0.383 \\
.386 \\
.391 \\
.394 \\
.396\end{array}$ & $\begin{array}{c}m \mu \\
17.0 \\
15.6 \\
14.4 \\
13.2 \\
12.0\end{array}$ & $\begin{array}{l}0.900 \\
.900 \\
.900 \\
.900 \\
.900\end{array}$ & $\begin{array}{l}237 \\
243 \\
243 \\
255 \\
166\end{array}$ \\
\hline $\begin{array}{l}366 \\
355 \\
345 \\
337 \\
329\end{array}$ & $\begin{array}{l}4.35 \\
2.80 \\
1.80 \\
1.80 \\
1.50\end{array}$ & $\begin{array}{l}.398 \\
.397 \\
.389 \\
.380 \\
.370\end{array}$ & $\begin{array}{r}11.0 \\
10.0 \\
9.1 \\
8.3 \\
7.6\end{array}$ & $\begin{array}{l}.900 \\
.897 \\
.892 \\
.890 \\
.888\end{array}$ & $\begin{array}{c}111 \\
78.6 \\
57.0 \\
64.1 \\
59.7\end{array}$ \\
\hline $\begin{array}{l}322 \\
315 \\
309 \\
302 \\
296\end{array}$ & $\begin{array}{l}1.27 \\
.74 \\
.58 \\
.36 \\
.30\end{array}$ & $\begin{array}{l}.360 \\
.351 \\
.338 \\
.322 \\
.308\end{array}$ & $\begin{array}{l}7.1 \\
6.6 \\
6.2 \\
5.8 \\
5.4\end{array}$ & $\begin{array}{l}.885 \\
.881 \\
.879 \\
.874 \\
.871\end{array}$ & $\begin{array}{l}56.1 \\
36.2 \\
31.5 \\
22.0 \\
20.7\end{array}$ \\
\hline $\begin{array}{l}291 \\
286 \\
281 \\
277 \\
273 \\
\text { a d }\end{array}$ & $\begin{array}{l}.16 \\
.20 \\
.15 \\
.11 \\
.132\end{array}$ & $\begin{array}{l}.295 \\
.278 \\
.264 \\
.250 \\
.239 \\
\end{array}$ & $\begin{array}{l}5.0 \\
4.7 \\
4.4 \\
4.1 \\
3.8\end{array}$ & $\begin{array}{l}.869 \\
.865 \\
.861 \\
.859 \\
.856\end{array}$ & $\begin{array}{l}12.5 \\
17.7 \\
15.0 \\
12.5 \\
17.0\end{array}$ \\
\hline $\begin{array}{r}269 \\
266 \\
262 \\
259 \\
\text { 棌 }\end{array}$ & $\begin{array}{l}.098 \\
.078 \\
.089 \\
.063\end{array}$ & $\begin{array}{r}.229 \\
.220 \\
.210 \\
.204 \\
\end{array}$ & $\begin{array}{l}3.6 \\
3.4 \\
3.2 \\
3.1\end{array}$ & $\begin{array}{l}.852 \\
.850 \\
.848 \\
.844 \\
.890\end{array}$ & $\begin{array}{l}13.9 \\
12.3 \\
15.6 \\
11.8\end{array}$ \\
\hline $\begin{array}{l}256 \\
253 \\
252 \\
250\end{array}$ & $\begin{array}{l}.044 \\
.085 \\
.120 \\
.089\end{array}$ & $\begin{array}{l}.198 \\
.194 \\
.187 \\
.183\end{array}$ & $\begin{array}{l}3.0 \\
2.9 \\
2.9 \\
2.8\end{array}$ & $\begin{array}{l}.841 \\
.839 \\
.837 \\
.835 \\
\end{array}$ & $\begin{array}{r}8.8 \\
18.0 \\
26.7 \\
20.8\end{array}$ \\
\hline $\begin{array}{l}247 \\
244 \\
238 \\
234\end{array}$ & $\begin{array}{l}.041 \\
.028 \\
.013 \\
.009\end{array}$ & $\begin{array}{r}.180 \\
.170 \\
.160 \\
.150\end{array}$ & $\begin{array}{l}2.8 \\
2.7 \\
2.7 \\
2.6\end{array}$ & $\begin{array}{l}.830 \\
.830 \\
.820 \\
.810\end{array}$ & $\begin{array}{l}9.8 \\
7.3 \\
3.7 \\
2.8\end{array}$ \\
\hline
\end{tabular}




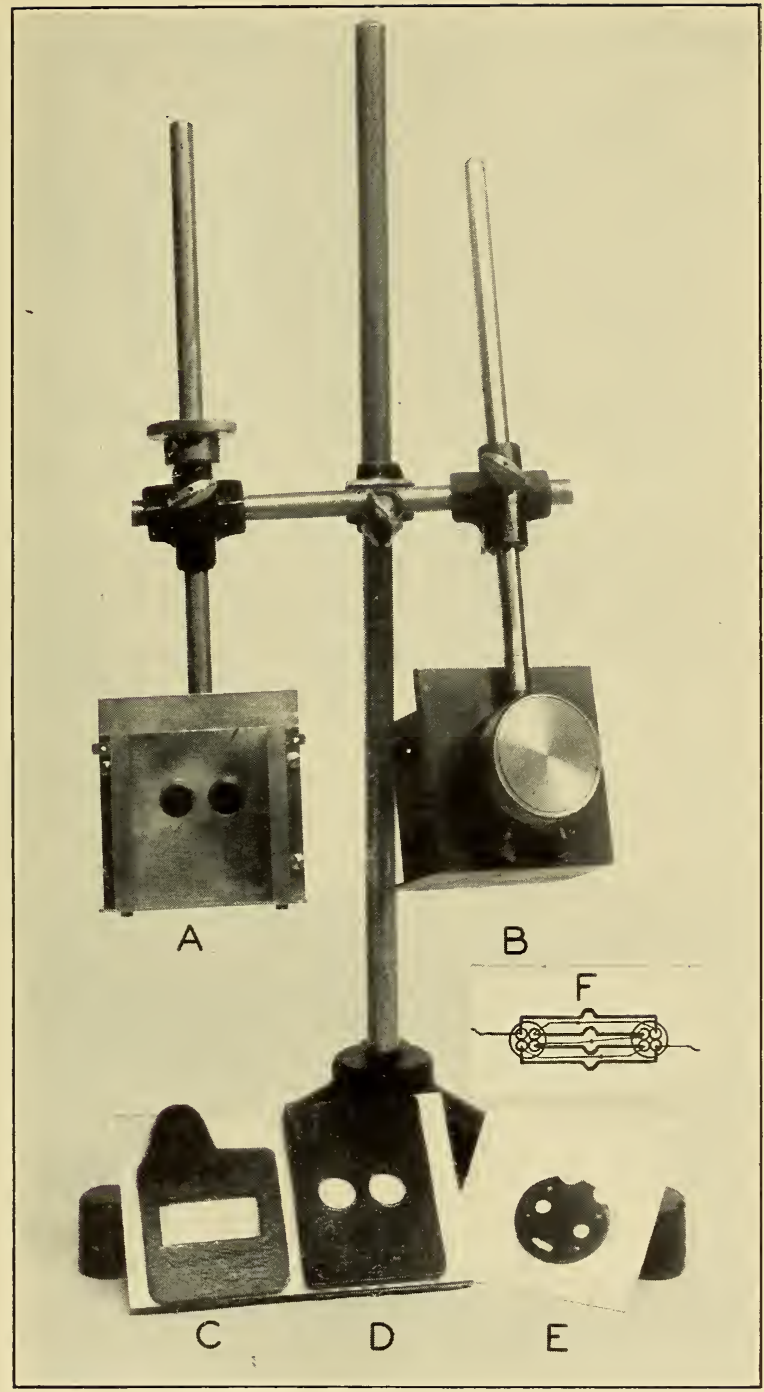

Figure 1.-Balanced thermocouple and filter radiometer

$A$, Front view of unfinished mounting; $B$, rear view of an early model; $C$, holder of Noviol A glass; $D$, holder of quartz and barium flint glass filters; $E$, bakelite thermopile mounting; $F$, rear view of balanced thermopile with individual receivers of tin (diameter $1.2 \mathrm{~mm}$, thickness $0.02 \mathrm{~mm}$ ) attached with shellac varnish to an electrically insulated disk of aluminum (diameter $5.0 \mathrm{~mm}$, thickness $0.01 \mathrm{~mm}$ ). The insulation is a thin film of cellulose lacquer. 


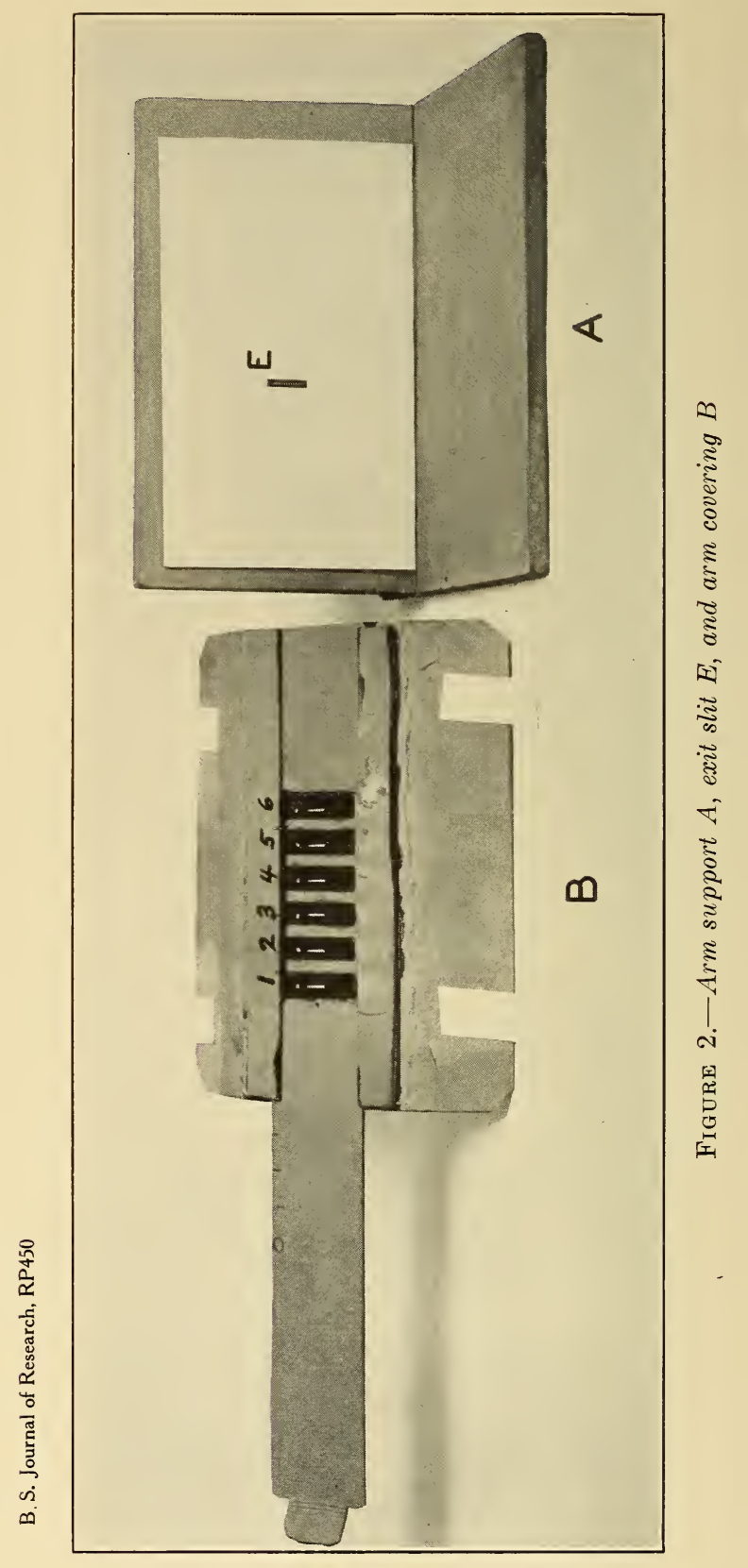


2. DETERMINATION OF THE TOTAL ULTRA-VIOLET RADIANT FLUX OF WAVE LENGTHS LESS THAN $313 \mathrm{~m} \mu$ IN THE HETEROGENEOUS SOURCE

The total ultra-violet radiation of wave lengths less than $313 \mathrm{~m} \mu$ was determined, in absolute value, by the balanced thermocouple and filter method (fig. 1) as described on page 740 of the preceding paper (3).

Representative data for the white flame (sunshine) carbon arc are given in Table 2, in which column 1 gives the observed galvanometer deflection on insertion of the filters, and column 3 is the value after correction for the long wave length visible and infra-red radiation transmitted by the Noviol filter.

The most important factor, $F$, to be determined is the one for evaluating the amount of ultra-violet of wave lengths less than and including $313 \mathrm{~m} \mu$ relative to the total amount shut out by the barium flint glass exclusion filter. Following the method outlined on page 741 of the preceding paper (3) the sum of the intensities of the wave lengths shorter than and including $313 \mathrm{~m} \mu$ in column 2 of Table 3 , represents the total amount emitted; and column 6 is the total amount excluded by the barium flint glass filter. The ratio of these two summations (252.0/396.3) is the factor $F=0.636$ used in column 4 of Table 2. This factor would, of course, be different for a barium flint glass filter having a different ultra-violet spectral transmission (16) from the one used; but the use of such a filter would change the value in column 1 of Table 2 and, within the errors of observation, would not affect the value sought, which is given in column 6 of Table 3 .

As shown in the preceding paper (3) the value of the total ultraviolet of wave lengths less than $313 \mathrm{~m} \mu$, obtained by the filter method, is somewhat higher than the value obtained by summation of the spectral measurements. However, from the herein recorded physiological (erythemal) measurements, in which there is no systematic difference between the physiological and radiometric evaluation of the ultra-violet emitted by various sources, it appears that the filter method gives an accurate appraisal of the ultra-violet emitted by the source as a whole, including the reflector. Such an appraisal of the radiation from a lamp and its reflector is not practicable by spectral energy measurements.

TABLE 2.-Integrated ultra-violet radiation of wave lengths less than, and including $313 \mathrm{m \mu}$, at $30 \mathrm{~cm}$, from a white flame carbon arc, as determined by a balanced thermopile and exclusion filter radiometer

\begin{tabular}{|c|c|c|c|c|c|}
\hline $\begin{array}{c}\text { Observed } \\
\text { galvanom- } \\
\text { eter defiec- } \\
\text { tion }\end{array}$ & $\begin{array}{c}\text { Infra-red } \\
\text { correction }\end{array}$ & $\begin{array}{c}\text { Difference } \\
1-2\end{array}$ & $\begin{array}{c}\text { Factor F } \\
\text { Table 3 }\end{array}$ & $\begin{array}{c}\text { Thermopile } \\
\text { sensitivity } \\
1 \text { cm= } \\
\mu w / \mathrm{cm}^{2}\end{array}$ & $\begin{array}{c}\text { Total ultra- } \\
\text { violet radi- } \\
\text { ation in } \\
\mu w / \mathrm{cm}^{2} \\
\text { columns } \\
3 \times 4 \times 5\end{array}$ \\
\hline 1 & 2 & 3 & 4 & 5 & 6 \\
\hline$c m$ & $c m$ & $c m$ & 0.636 & 124.6 & 397.0 \\
\hline 6.92 & 1.91 & 5.01 & 0.636 & \\
\hline
\end{tabular}

$117348-32-7$ 
TABLE 3.-Determination of the factor $F$ (used in Table 2) for reducing the observed spectral intensity to radiation of wave lengths less than and including $313 \mathrm{m \mu}$; also the calculated spectral erythemogenic efficiency of a white flame carbon arc

[The value of the factor $F$ is $252.0 \div 396.3=0.636$ ]

\begin{tabular}{|c|c|c|c|c|c|c|c|}
\hline $\begin{array}{l}\text { Wave } \\
\text { length }\end{array}$ & $\begin{array}{l}\text { Relative } \\
\text { intensity }\end{array}$ & $\begin{array}{l}\text { Trans- } \\
\text { mission } \\
\text { quartz } \\
\text { minus } \\
\text { barium } \\
\text { flint }\end{array}$ & $\begin{array}{c}\text { Trans- } \\
\text { mission } \\
\text { water } \\
\text { cell }\end{array}$ & $\begin{array}{c}\text { Trans- } \\
\text { mission } \\
\text { fluorite } \\
\text { on ther- } \\
\text { mopile }\end{array}$ & $\begin{array}{c}\text { Radiation } \\
\text { excluded } \\
\text { by ba- } \\
\text { rium flint } \\
\text { glass; col- } \\
\text { umns } 2 \times \\
3 \times 4 \times 5\end{array}$ & $\begin{array}{l}\text { Ery- } \\
\text { themic } \\
\text { response }\end{array}$ & $\begin{array}{l}\text { Ery- } \\
\text { themic } \\
\text { value; } \\
\text { columns } \\
2 \times 7\end{array}$ \\
\hline 1 & 2 & 3 & 4 & 5 & 6 & 7 & 8 \\
\hline $\begin{array}{c}m_{\mu} \\
435 \ldots . . . \\
430 \ldots . . \\
425 \ldots \ldots \\
420 \ldots \ldots \\
415 \ldots . . \\
\end{array}$ & $\begin{array}{l}238 \\
240 \\
242 \\
243 \\
244\end{array}$ & $\begin{array}{r}0.010 \\
.011 \\
.012 \\
.013 \\
.015\end{array}$ & $\begin{array}{r}0.880 \\
.880 \\
.880 \\
.880 \\
.880\end{array}$ & $\begin{array}{r}0.900 \\
.900 \\
.900 \\
.900 \\
.900\end{array}$ & $\begin{array}{l}1.9 \\
2.1 \\
2.3 \\
2.5 \\
2.9\end{array}$ & & \\
\hline $\begin{array}{l}410 \ldots \\
405 \\
400 \\
395 \\
390 . \\
\end{array}$ & $\begin{array}{l}244 \\
244 \\
246 \\
251 \\
255\end{array}$ & $\begin{array}{l}.018 \\
.020 \\
.023 \\
.027 \\
.030\end{array}$ & $\begin{array}{l}.880 \\
.880 \\
.880 \\
.880 \\
.880\end{array}$ & $\begin{array}{l}.900 \\
.900 \\
.900 \\
.900 \\
.895\end{array}$ & $\begin{array}{l}3.5 \\
3.9 \\
4.5 \\
5.4 \\
6.0\end{array}$ & & \\
\hline $\begin{array}{l}385 \ldots \\
380 \ldots \\
375 \ldots \\
370 \ldots \\
365 \ldots \\
\end{array}$ & $\begin{array}{l}216 \\
178 \\
150 \\
129 \\
108\end{array}$ & $\begin{array}{l}.035 \\
.040 \\
.050 \\
.055 \\
.067\end{array}$ & $\begin{array}{l}.875 \\
.875 \\
.875 \\
.875 \\
.875\end{array}$ & $\begin{array}{l}.895 \\
.890 \\
.890 \\
.890 \\
.890\end{array}$ & $\begin{array}{l}5.9 \\
5.5 \\
5.8 \\
5.5 \\
5.6\end{array}$ & & \\
\hline $\begin{array}{l}360 \ldots \\
355 \ldots \\
350 \ldots \\
345 \ldots \\
340 \ldots\end{array}$ & $\begin{array}{l}94 \\
78.6 \\
67 \\
57 \\
62\end{array}$ & $\begin{array}{l}.090 \\
.115 \\
.155 \\
.200 \\
.270\end{array}$ & $\begin{array}{l}.875 \\
.870 \\
.870 \\
.870 \\
.870\end{array}$ & $\begin{array}{l}.890 \\
.885 \\
.885 \\
.885 \\
.880\end{array}$ & $\begin{array}{r}6.6 \\
7.0 \\
8.0 \\
8.8 \\
12.8\end{array}$ & & \\
\hline $\begin{array}{l}335 \ldots \\
330 \ldots \\
325 \ldots \\
320 \ldots \\
315 \ldots \\
\end{array}$ & $\begin{array}{l}63 \\
61 \\
57 \\
48 \\
36.2\end{array}$ & $\begin{array}{l}.375 \\
.520 \\
.775 \\
.805 \\
.877\end{array}$ & $\begin{array}{l}.865 \\
.865 \\
.865 \\
.865 \\
.860\end{array}$ & $\begin{array}{l}.880 \\
.880 \\
.880 \\
.875 \\
.875\end{array}$ & $\begin{array}{l}18.0 \\
24.1 \\
33.6 \\
29.2 \\
23.9\end{array}$ & 0.00 & 0.00 \\
\hline $\begin{array}{l}310 \ldots \\
305 \\
300 \ldots \\
295\end{array}$ & $\begin{array}{l}32.4 \\
26.2 \\
21.4 \\
19.0\end{array}$ & $\begin{array}{l}.900 \\
.900 \\
.900 \\
.900\end{array}$ & $\begin{array}{l}.860 \\
.860 \\
.860 \\
.855\end{array}$ & $\begin{array}{l}.875 \\
.870 \\
.870 \\
.865\end{array}$ & $\begin{array}{l}21.9 \\
17.6 \\
14.4 \\
12.7\end{array}$ & $\begin{array}{l}.11 \\
.33 \\
.82 \\
.95\end{array}$ & $\begin{array}{r}3.56 \\
8.65 \\
17.55 \\
18.05\end{array}$ \\
\hline $\begin{array}{l}290 \ldots \\
285 \ldots \\
280 \ldots \\
275 \ldots\end{array}$ & $\begin{array}{l}13.3 \\
17.0 \\
14.3 \\
14.8\end{array}$ & $\begin{array}{l}.900 \\
.900 \\
.900 \\
.900\end{array}$ & $\begin{array}{l}.855 \\
.850 \\
.850 \\
.845\end{array}$ & $\begin{array}{l}.860 \\
.855 \\
.850 \\
.845\end{array}$ & $\begin{array}{r}8.8 \\
11.1 \\
9.3 \\
9.5\end{array}$ & $\begin{array}{l}.26 \\
.09 \\
.06 \\
.07\end{array}$ & $\begin{array}{l}3.46 \\
1.53 \\
.86 \\
1.04\end{array}$ \\
\hline $\begin{array}{l}270 \ldots \\
265 \\
260 \ldots \\
255 \ldots\end{array}$ & $\begin{array}{l}14.5 \\
13.3 \\
13.0 \\
12.5\end{array}$ & $\begin{array}{l}.900 \\
.900 \\
.900 \\
.900\end{array}$ & $\begin{array}{l}.845 \\
.840 \\
.840 \\
.835\end{array}$ & $\begin{array}{l}.840 \\
.835 \\
.830 \\
.825\end{array}$ & $\begin{array}{l}9.3 \\
8.4 \\
8.2 \\
7.7\end{array}$ & $\begin{array}{l}.13 \\
.25 \\
.42 \\
.54\end{array}$ & $\begin{array}{l}1.89 \\
3.32 \\
5.46 \\
6.75\end{array}$ \\
\hline $\begin{array}{l}250 \ldots \\
245 \ldots \\
240 \\
235 \ldots\end{array}$ & $\begin{array}{r}20.9 \\
8.0 \\
4.8 \\
3.0\end{array}$ & $\begin{array}{l}.900 \\
.900 \\
.900 \\
.900\end{array}$ & $\begin{array}{l}.830 \\
.825 \\
.820 \\
.815\end{array}$ & $\begin{array}{l}.820 \\
.810 \\
.800 \\
.790\end{array}$ & $\begin{array}{r}12.8 \\
4.8 \\
2.8 \\
1.7\end{array}$ & $\begin{array}{l}.56 \\
.57 \\
.56 \\
.56\end{array}$ & $\begin{array}{r}11.70 \\
4.56 \\
2.69 \\
1.68\end{array}$ \\
\hline Total & 1252.0 & & & & 2396.3 & & ${ }^{3} 92.75$ \\
\hline
\end{tabular}

1 Total present of wave lengths $313 \mathrm{~m} \mu$ and less.

2 Total excluded by barium flint glass filter.

Erythemogenic efficiency $=92.75 \div 252.0=36.8$ per cent.

\section{DETERMINATION OF THE MINIMUM PERCEPTIBLE ERYTHEMA} USING HOMOGENEOUS RADIATION

As already stated there is a wide variation in erythemic susceptibility of the same person under different atmospheric conditions, and of different parts of the body (for example, the inner forearm; see Table 4 , W. W. C., January 8, 1932) separated by a distance of only $15 \mathrm{~cm}$ or even less. Closely adjacent areas were therefore selected for the 
erythema tests. Moreover, the standardization test of the minimum erythemic reaction for homogeneous radiation of wave length $297 \mathrm{~m} \mu$ was made within a day, or not more than a few days preceding the erythemal tests with heterogeneous radiation from the lamp under investigation.

In view of the necessity of making these two types of erythemal tests, in addition to the quartz-fluorite achromatic lens spectroradiometer for determining the spectral energy data of the lamp under investigation, a large quartz lens and prism spectropyrheliometer (4) was kept in operation for isolating the homogeneous radiation stimulus of wave length $297 \mathrm{~m} \mu$, used as a standard. Owing to its high light gathering power, this spectroradiometer (which consists of two plano-convex quartz lenses, $6 \mathrm{~cm}$ in diameter, $18 \mathrm{~cm}$ focal length, and a $60^{\circ}$ quartz prism with faces 6 by $7 \mathrm{~cm}$ ) transmits a fairly large $(0.3$ by $10 \mathrm{~mm}$ ) radiation stimulus of wave length $297 \mathrm{~m} \mu$, having a flux of 300 to $350 \mu \mathrm{w} / \mathrm{cm}^{2}$, which produces an erythema in 1 to 3 minutes, depending upon the susceptibility of the skin. In this test, the exposures are made in intervals of 10 seconds, beginning the series with a suberythemal exposure and closing with some of the exposures longer than required to produce a minimum perceptible erythema. From a series of 6 to 8 exposures (some duplicated on different parts of the arm) it is possible to select the exposure giving a minimum perceptible erythema.

TABLE 4.-Energy of wave lengths less than and including 313 mu required to produce a minimum perceptible erythema (M. P. E.) using widely different sources of heterogeneous ultra-violet radiation as compared with spectrally homogeneous radiation of wave length $297 \mathrm{~m} \mu$, the wave length of maximum erythemogenic effectiveness

[ The ultra-violet radiant flux (u. v. Q.) of wave lengths less than and including $313 \mathrm{~m} \mu$, is given in microwatts per $\mathrm{cm}^{2}\left(\mu \mathrm{w} / \mathrm{cm}^{2}\right)$. Region of body exposed: $L=$ left; $R=$ right; $F=$ forearm; $U=$ upper $\left.\operatorname{arm}\right]$

\section{Source}

\begin{tabular}{|c|c|c|c|c|c|c|c|c|c|c|c|c|}
\hline \multicolumn{6}{|c|}{$\lambda 297 \mathrm{~m} \mathrm{\mu}$} & \multicolumn{7}{|c|}{ The sun } \\
\hline \multirow{2}{*}{ Observer } & \multirow{2}{*}{ Date } & \multirow{2}{*}{$\begin{array}{l}\text { U. v. Q. } \\
\mu \mathrm{W} / \mathrm{cm}^{2}\end{array}$} & \multirow{2}{*}{$\begin{array}{c}\text { Time } \\
\text { for } \\
\text { M. P. E. }\end{array}$} & \multirow{2}{*}{$\begin{array}{c}\text { Total } \\
\text { energy }\end{array}$} & \multirow{2}{*}{$\begin{array}{c}\text { Region } \\
\text { exposed }\end{array}$} & \multirow{2}{*}{$\begin{array}{l}\text { Dist. } \\
\text { from } \\
\text { source }\end{array}$} & \multirow{2}{*}{$\begin{array}{l}\text { u. v. Q. } \\
\mu \mathrm{W} / \mathrm{cm}^{2}\end{array}$} & \multicolumn{2}{|c|}{$\begin{array}{l}\text { Time for } \\
\text { M. P. E. }\end{array}$} & \multirow{2}{*}{$\begin{array}{l}\text { Total } \\
\text { energy }\end{array}$} & \multicolumn{2}{|c|}{$\begin{array}{l}\text { Erythemo- } \\
\text { genic effi- } \\
\text { ciency }\end{array}$} \\
\hline & & & & & & & & $\begin{array}{c}\text { Ob- } \\
\text { served }\end{array}$ & $\begin{array}{l}\text { Cal- } \\
\text { cu- } \\
\text { lated }\end{array}$ & & $\begin{array}{l}\text { Ob- } \\
\text { served }\end{array}$ & $\begin{array}{l}\text { Cal- } \\
\text { cu- } \\
\text { lated }\end{array}$ \\
\hline 1 & 2 & 3 & 4 & 5 & 6 & 7 & 8 & 9 & 10 & 11 & 12 & 13 \\
\hline $\begin{array}{l}\text { W. W. C_ } \\
\text { R. S.... }\end{array}$ & $\begin{array}{r}1931 \\
\text { June } \\
2 \\
3 \\
\end{array}$ & $\begin{array}{l}395 \\
395\end{array}$ & \begin{tabular}{|r|} 
Seconds \\
90 \\
120
\end{tabular} & $\begin{array}{c}\text { Ergs. } \\
355,500 \\
474,000\end{array}$ & $\begin{array}{l}\text { L. U. } \\
\text { R. F. }\end{array}$ & \begin{tabular}{|c|}
$c m$ \\
$c m$ \\
\end{tabular} & $\begin{array}{l}90 \\
78\end{array}$ & $\begin{array}{c}\text { Min- } \\
\text { utes } \\
32 \\
45\end{array}$ & $\begin{array}{r}\text { Min- } \\
\text { utes } \\
30 \\
46\end{array}$ & $\begin{array}{c}\text { Ergs. } \\
1,728,000 \\
2,106,000\end{array}$ & $\begin{array}{l}\text { Per } \\
\text { cent } \\
20.6 \\
22.5\end{array}$ & $\begin{array}{r}\text { Per } \\
\text { cent } \\
22 \\
22\end{array}$ \\
\hline $\begin{array}{l}\text { J.M. } \mathrm{H} \\
\dot{\mathrm{W}} \cdot \mathbf{W} \cdot \mathrm{C}\end{array}$ & $\begin{array}{l}27 \\
22\end{array}$ & $\begin{array}{l}316 \\
316\end{array}$ & $\begin{array}{l}60 \\
70\end{array}$ & $\begin{array}{l}189,600 \\
221,200\end{array}$ & $\begin{array}{l}\text { L. U. } \\
\text { L. U. }\end{array}$ & & $\begin{array}{l}69 \\
88\end{array}$ & $\begin{array}{l}21 \\
20\end{array}$ & $\begin{array}{l}21 \\
19\end{array}$ & $\begin{array}{r}869,400 \\
1,056,000\end{array}$ & $\begin{array}{l}21.8 \\
20.9\end{array}$ & $\begin{array}{l}22 \\
22\end{array}$ \\
\hline & & & & & & Gener & al Electr & ric mazc & $\begin{array}{l}\text { la S-1 } \\
\text { eflecto }\end{array}$ & ; quartz g & ass bul & lb; no \\
\hline $\begin{array}{l}\text { W. W. C. } \\
\text { W. W. C. } \\
\text { J. M. H. }\end{array}$ & $\begin{array}{l}10 \\
17 \\
17\end{array}$ & $\begin{array}{l}295 \\
316 \\
316\end{array}$ & $\begin{array}{l}60 \\
70 \\
60\end{array}$ & $\begin{array}{l}237,000 \\
221,200 \\
189,600\end{array}$ & $\begin{array}{l}\text { L. U. } \\
\text { L. U. } \\
\text { L. U. }\end{array}$ & $\begin{array}{l}20 \\
25 \\
25\end{array}$ & $\begin{array}{l}605 \\
387 \\
387\end{array}$ & $\begin{array}{c}\text { Sec- } \\
\text { onds } \\
130 \\
200 \\
170\end{array}$ & $\begin{array}{r}\text { Sec- } \\
\text { onds } \\
125 \\
182 \\
156\end{array}$ & $\begin{array}{l}786,500 \\
774,000 \\
657,900\end{array}$ & $\begin{array}{l}30.1 \\
28.6 \\
28.8\end{array}$ & $\begin{array}{l}31.4 \\
31.4 \\
31.4\end{array}$ \\
\hline
\end{tabular}


TABLE 4.-Energy of wave lengths less than and including $313 \mathrm{m \mu}$ required to produce a minimum perceptible erythema (M.P.E.) using widely different sources of heterogeneous ultra-violet radiation as compared with spectrally homogeneous radiation of wave length $297 \mathrm{m \mu}$, the wave length of maximum erythemogenic effectiveness-Continued

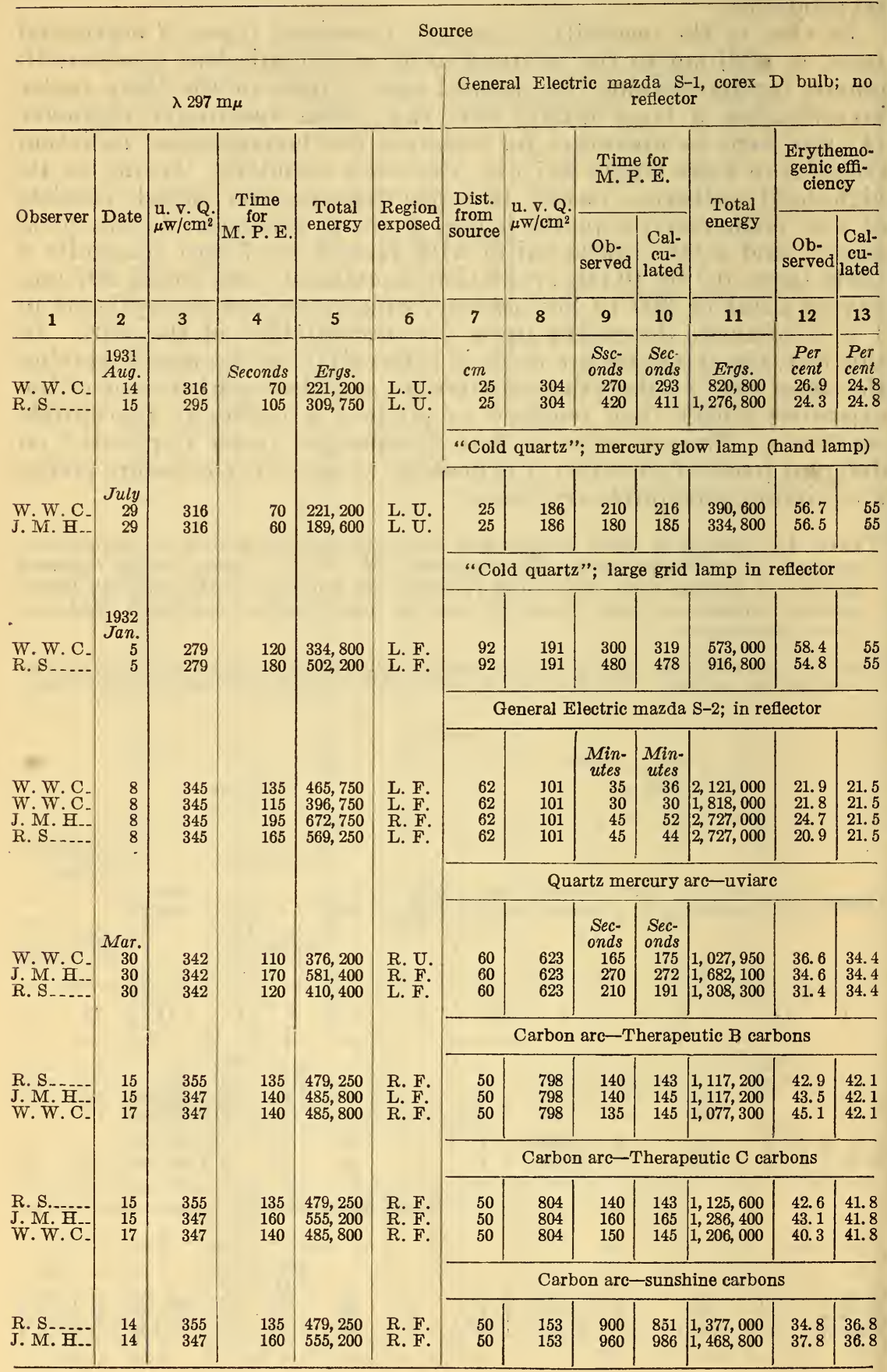


The "minimum perceptible erythema" is not sharply defined. This is easily demonstrated by wiping the skin with alcohol, on the day following the exposure, which brings out, for an hour or more, weak exposures that previously had shown no visible erythema. On the other hand, by wiping the skin with xylol, weakly visible erythemas may be rendered invisible for a short time. Furthermore, exposures that are a year old, and no longer show pigmentation in daylight, are rendered distinctly visible by the ultra-violet light transmitted through a Corning G986A blue-purple filter.

Nevertheless, in spite of these limitations, it is possible by careful procedure and observation, to procure reliable comparisons of the intensity of ultra-violet radiation of different sources by means of the erythema produced.

The various details in determining the spectral erythemic response of the untanned human skin are described in a preceding paper (5). Briefly stated the exit slit (fig. 2) of metal $0.1 \mathrm{~mm}$ in thickness, with beveled edges turned away from the incident radiation in order to obtain a sharp separation, is mounted upon a rigid support, which, after focusing the slit upon the spectral line that is to be isolated, is securely attached to the spectrometer arm. The erythemal and the radiometric measurements are made on the isolated spectral line, just outside the exit slit.

In order to obtain a calibration in absolute value and to increase the accuracy of the determinations of the total energy required to produce a minimum perceptible erythema, the thermopile is temporarily mounted close to and directly over the outside of the exit slit, $E$, in Figure 2 (to completely intercept and measure the intensity of the spectral line after emerging through the slit) and exposed to the standard of radiation. After this calibration is completed, the exit slit is focused upon the spectral line $(297 \mathrm{~m} \mu)$, the support is securely clamped to the spectrometer arm and the energy measurements are made. Immediately thereafter (that is, without moving the lamp, which is necessary in relighting it) the thermopile is removed and the erythemal exposures are made. While this procedure is not absolutely necessary, it is convenient and adds to the accuracy of the work.

The exposures to the homogeneous radiation (as well as the exposures to heterogeneous radiation) were usually made in the afternoon. This permitted observation during the evening and then again the following morning of the erythema produced. For this purpose, each observer carried an index card, containing a record of the identification marks (usually small indelible pencil marks) and notes regarding the time of the exposures. The following day the three observers conferred on the reactions obtained.

From the data on the energy required to produce a minimum perceptible erythema, using homogeneous radiation, a calculation was then made of the time of exposure to the source of heterogeneous radiation, necessary to produce a minimum perceptible erythema. This calculation is based upon the total ultra-violet of wave lengths less than and including $313 \mathrm{~m} \mu$, observed by the balanced thermopile and filter radiometer, and based upon the erythemogenic efficiency, which is obtained from the rubescence curve, as explained in a subsequent part of this paper. 


\section{DETERMINATION OF THE MINIMUM PERCEPTIBLE ERYTHEMA} PRODUCED BY HETEROGENEOUS ULTRA-VIOLET RADIATION

The procedure in making the erythema tests using different sources' of heterogeneous radiation was more varied than when the exposures were made to homogeneous radiation.

In making the exposures to the sun, the inner, upper, or lower arm was covered with a black cloth containing a series of small rectangular openings, which were covered in succession after definite intervals of exposure.

In order to reduce the heat from the lamp in making the erythema tests on the Mazda S-1 lamp, different parts of the arm were exposed by moving it back of a single slot $(0.5 \mathrm{by} 10 \mathrm{~mm})$ cut in a large cardboard screen, which was rigidly mounted at a fixed distance from the side of the lamp. Between this screen and the lamp was another screen of white cardboard, to further reduce the heating of the screen and hence the arm.

In the experiments on the Mazda S-2 lamp and the carbon arc lamp, the arm was covered with a cardboard screen (fig. 2) containing six closely adjoining openings $(0.5$ by $6 \mathrm{~mm}$ ), which were covered successively by means of a sliding shutter. Close to the end of each slot was a small hole for marking the location of the exposure with an indelible pencil.

Some of the exposures ( 6 to 8 in all) were purposely made shorter and others longer than the calculated time to produce a minimum perceptible ery thema. The short exposures (3 to 4 minutes) differed by intervals of 10 seconds, while for the longer exposures, the intervals were from 1 to 3 minutes.

As mentioned in a previous paper (5) the erythema produced by radiation of wave lengths less than about $270 \mathrm{~m} \mu$ is superficial and becomes visible within about an hour after exposure. If the exposure is mild, the erythema begins to disappear in the course of 5 hours. On the other hand, the erythema produced by the more deeply penetrating radiation of wave lengths at 297 to $313 \mathrm{~m} \mu$, does not become visible before the expiration of 4 to 6 hours and it continues for a day or for many days, depending upon the severity of the exposure.

In sources like the blue flame carbon arc (fig. 4) and the quartz mercury arc, which contain an abundance of short wave length ultraviolet radiation, the erythema appears within about an hour after exposure. Furthermore, depending upon the relative amount of erythemogenic radiation in the two spectral regions (at $250 \mathrm{~m} \mu$ and at $297 \mathrm{~m} \mu$, respectively, see fig. 4) and the total time of exposure, the development of the erythema appears in two stages of maximum redness, caused by the two different rates of growth and decay of the overlapping reactions. While this phenomenon makes it more difficult to define the minimum perceptible erythema, there does not appear to be any definitely observable inhibitory ("antagonistic") or stimulative action of the one spectral region upon the other, in causing an erythema. This conclusion follows from the close agreement between the observed and the calculated erythemogenic efficiencies of the various sources differing widely in spectral distribution of ultra-violet radiation. The slightly higher values observed with the blue flame carbon arc lamp can be ascribed to the lack of exact knowledge of the spectral transmission of the spectrometer 
lenses and of the spectral erythemic response for wave lengths shorter than $245 \mathrm{~m} \mu$.

\section{COMPARISON OF ULTRA-VIOLET INTENSITIES BY RADIOMETRIC AND ERYTHEMAL OBSERVATIONS}

While the preliminary data given in the preceding paper (3) seemed sufficient to indicate that the ultra-violet intensity of a source can be determined radiometrically, and that, from the measurements so obtained, the duration of the exposure can be calculated, thus decreasing the hazard of burning the skin, nevertheless it seemed desirable to make a more extensive survey of specific types of sources offered for therapeutic purposes.

\section{DETERMINATION OF THE TOTAL ENERGY REOUIRED TO PRODUCE A MINIMUM PERCEPTIBLE ERYTHEMA USING THE STANDARD LINE AT $297 \mathrm{~m} \mu$}

The chief reasons for adopting homogeneous radiation of wave length $297 \mathrm{~m} \mu$ (more exactly $2,967 \mathrm{~A}$ ) as a standard of ery themal and radiometric comparison are $(a)$ because this emission line appears to coincide closely with the wave length of maximum erythemic susceptibility, (b) because this line is reproducible and easily obtainable in sufficient intensity for erythemal and radiometric measurements $(10)$, and $(c)$ because it is easily evaluated in absolute measure by comparison with a standard of radiation (9).

While the intensity of the quartz mercury lamp decreases with usage, the manner of evaluation in absolute units, at the exit slit of the monochromator, presents no obstacles such as would be encountered in attempting to use a source of heterogeneous ultra-violet as a standard of radiation. If an unchangeable source of heterogeneous ultra-violet radiation were available as a standard, all these tedious calibrations would be unnecessary.

In making a comparison of the erythemogenic action of different sources of heterogeneous ultra-violet radiation with that of the standard line $(297 \mathrm{~m} \mu)$ the exposures were made on parts of the inner forearm or on the inner upper arm that had never before been subjected to such erythemal tests; or, at least a year had elapsed since making similar exposure tests.

From the time of exposure, and the intensity, determined in absolute units, as described under Caption II, the total energy required to produce a minimum perceptible erythema is obtained. These data are given in columns 5 and 11 of Table 4 .

As shown in column 2 of Table 4 (data of June, 1931, to January 5, 1932) the intensity of the $297 \mathrm{~m} \mu$ line decreased with aging of the quartz burner (which was used extensively in laboratory measurements); and is much higher for a new burner that was installed in January, 1932. However, as already mentioned, since the source of the homogeneous radiation used in the erythema tests is evaluated at the exit slit of the spectroscope, it is unnecessary to take cognizance of absorption in the spectroscope or change in intensity with aging of the lamp. 
2. DETERMINATION OF THE TOTAL ENERGY REQUIRED TO PRODUCE A MINIMUM PERCEPTIBLE ERYTHEMA USING VARIOUS SOURCES OF HETEROGENEOUS ULTRA-VIOLET RADIATION

The flux of radiation of wave lengths less than and including $313 \mathrm{~m} \mu$ emitted by a heterogeneous source is obtained by the procedure outlined under Caption II. This involves measurements with the filter radiometer and a determination of the spectral energy curve in order to determine the factor $F$.

The time of exposure to produce a minimum perceptible erythema is given in column 9 of Table 4 . In this same table, column 8 gives the intensities observed at the point (column 7) of making the exposures. The product of the radiant flux (intensity) and the time of exposure gives the total energy required to produce a minimum perceptible erythema. These energy values are given in column 11 of Table 4.

\section{THE ERYTHEMOGENIC EFFICIENCY OF VARIOUS SOURCES OF ULTRA-VIOLET RADIATION}

The essential principle involved in evaluating the erythemogenic efficiency is the accurate determination of the total energy required to produce a minimum perceptible erythema, using homogeneous radiation of wave length $297 \mathrm{~m} \mu$, as compared with the total energy of wave lengths less than and including $313 \mathrm{~m} \mu$ required to produce a similar minimum perceptible erythema, when using heterogeneous sources of ultra-violet radiation. In this procedure no recognition is given to the fact that the erythemal reaction to the short wave lengths is more rapid in development and of shorter duration than to the longer wave lengths. In fact, on exposure to heterogeneous radiation (for example, the blue flame carbon arc) having intense emission bands in the region of 250 and $297 \mathrm{~m} \mu$, the two erythemic reactions seem to merge; the intensity of the erythema produced by the shorter ultra-violet wave lengths at $250 \mathrm{~m} \mu$, decreasing as the intensity of the erythema excited by the longer wave lengths in the region of $297 \mathrm{~m} \mu$, is increasing. However, the purpose of the investigation is to establish a method of estimating the intensity of the source and thus avoid burning of the skin by overexposure. This minimum perceptible erythema (that is, one that disappears in less than 24 hours and does not start pigmentation) is merely a useful criterion for indicating the physiological effectiveness of the radiation used.

To derive the erythemogenic efficiency of a heterogeneous source of ultra-violet radiation the ordinates of the observed spectral energy curve are multiplied by the respective ordinates of the spectral erythemic response curve (5). The resulting rubescence curve (see p. 735 and 747 of reference (3)) is analogous, in principle, to the luminosity curve of a source of light (10). The ratio of the shaded areas to the total areas of wave lengths less than $313 \mathrm{~m} \mu$, in Figures 3 and 4 is then the calculated erythemogenic efficiency of the source. The close agreement between the calculated erythemogenic efficiency and the experimental values obtained by observing the minimum perceptible erythema produced by the heterogeneous source (using the $297 \mathrm{~m} \mu$ line as a standard) is shown in columns 12 and 13 of Table 4.

For completeness in exposition of the subject a brief description is givenjof each source examined. 
(a). THE SUN

In view of the impracticability of observing solar spectral energy curves, under different atmospheric conditions, a standard spectral energy curve was adopted, as explained on page 733 of the preceding paper (3). The rubescence curve is shown in Figure 3. As explained in detail on page 743 of the preliminary paper (3), and as shown in Table 4, the agreement between the observed and the calculated values of the erythemogenic efficiency is as close as can be expected.

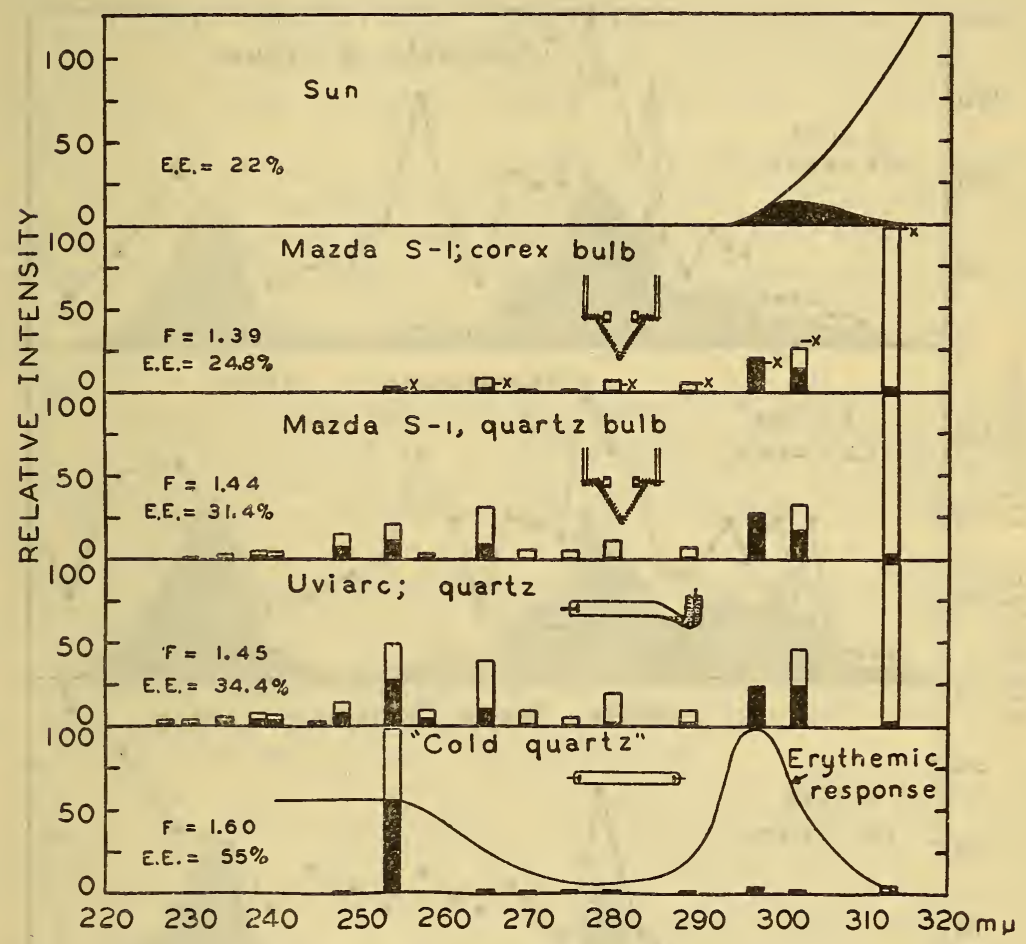

FIGURE 3.-Ultra-violet spectral energy distribution of various sources; also spectral erythemic response curve of the untanned skin and (the shaded areas) the rubescence energy which is the product of the spectral energy and the spectral erythemic response

$E . E .=$ ery themogenic efficiency; the ratio of the shaded area to the total area. $F=$ factor " $F$."

(b) THE CARBON ARC LAMP

The particular kinds of electrodes used were the white flame ("sunshine"), the blue flame ("therapeutic B"), and the polymetallic cored carbon electrode ("therapeutic C") made by the National Carbon Co. Similar spectral energy measurements on the carbon arc were made some years ago (11).

The electrodes, which were $10 \mathrm{~mm}$ in diameter, were operated on 26.5 amperes, 33 volts (across the arc) of an a. c. circuit. They were operated in a horizontal position, in a lamp that was provided with an automatic motor-feed mechanism. Finding that the magnet controls of the feed mechanism affected the galvanometer, the motorfeed device was operated by hand with a double-throw switch for 
making the adjustment of the arc length (potential held at 33 volts) when no radiometric readings were in progress.

In order to produce a wide, uniformly irradiated field, a flat aluminum plate, having a finely etched surface, was placed back of the arc.

Under these rigidly controlled conditions, radiometric measurements, made at different times upon different samples and upon different lengths of the same kind of carbons, gave values that were in agreement within less than 1 per cent.

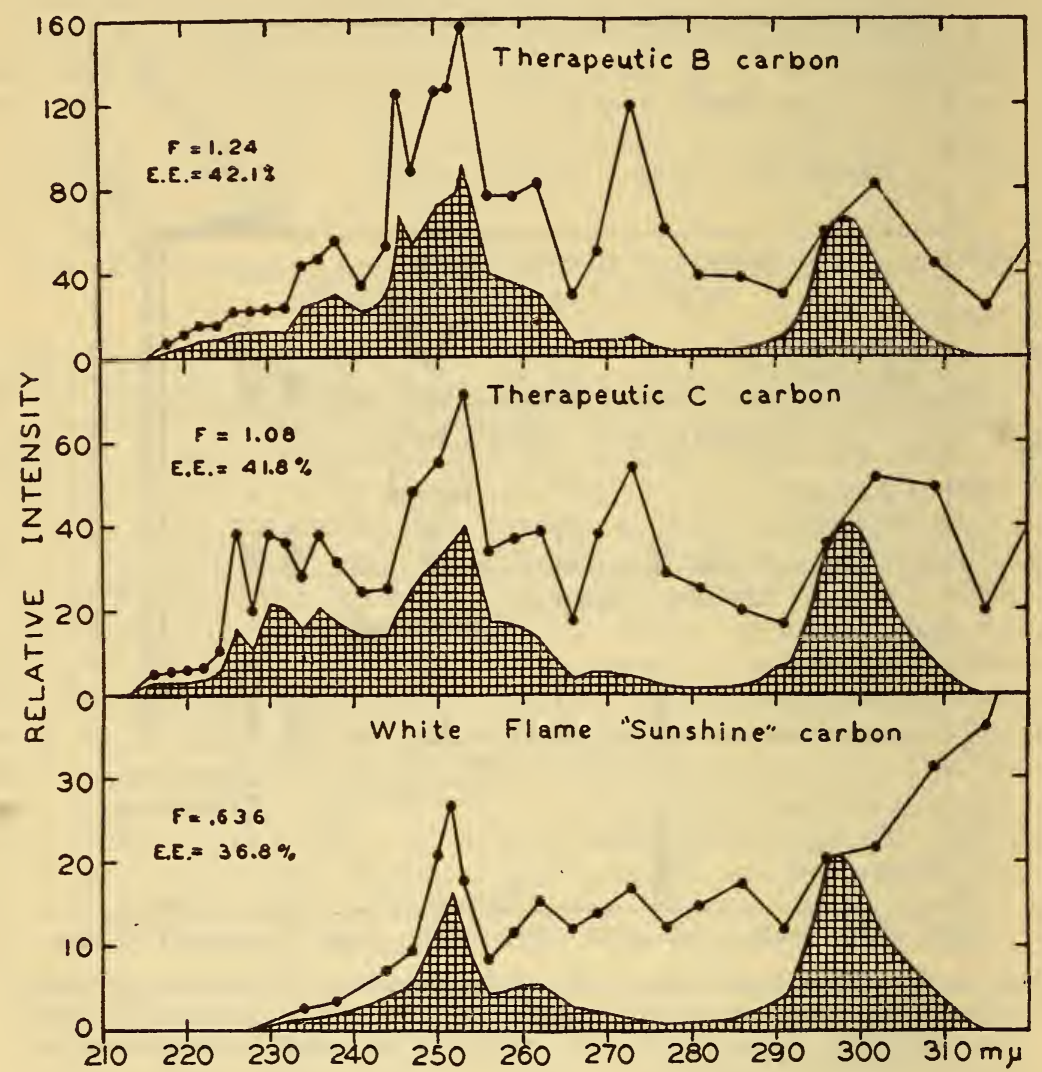

FIGURE 4.-Spectral energy curves of carbon arcs, and (the shaded areas) rubescence curves which are the product of the spectral energy and the spectral erythemic response

$E . E .=$ erythemogenic efficiency; the ratio of the shaded area to the total area. $F=$ factor " $F$."

The spectral energy curves, observed with a quartz-fluorite achromatic spectrometer, reduced to the normal spectrum and corrected for instrumental absorption as described under a preceding caption, are depicted in Figure 4. The shaded area under the, rubescence curve shows the large part of the erythemic effect contributed by the radiation emitted at 240 to $280 \mathrm{~m} \mu$, amounting to about 68 per cent of the total in the therapeutic B electrodes.

Attention has already been called to the intense emission in the region of $275 \mathrm{~m} \mu$, in the therapeutic $\mathrm{C}$ carbon, which may perhaps have a therapeutic action, but does not cause a marked erythema. 
Measurements were made of a new type of General Electric Mazda "sun lamp" (types S-1 and S-2) in which the arc discharge occurs at the top of a V-shaped helically wound tungsten filament.

The Mazda S-1 lamp was operated without a reflector. Two models of this lamp were examined $(a)$ an experimental lamp in a quartz bulb kindly supplied by the General Electric Lamp Research Laboratory, and $(b)$ a commercial lamp in a bulb of Corex D glass, which is intentionally made to be practically opaque to radiation of wave lengths less than about $280 \mathrm{~m} \mu$. The measurements were made on the radiation emanating from the side of the lamp, perpendicular to the plane through the $V$-shaped tungsten filament. The data on these lamps are given in Table 4.

The Mazda S-2 lamp was operated in its reflector. The radiation from this lamp is obtained entirely by reflection. All the observations were made at a fixed distance below the aluminum cap that covers the lower half of the bulb of the lamp. The erythemogenic efficiency and the intensity at a distance of $62 \mathrm{~cm}$ (2 feet) below the bulb of the lamp is practically the same as noon day summer sunlight. (See Table 4.)

The spectral energy data on the Mazda S-1 lamp in a Corex D bulb are depicted in Figure 3 . The crosses $(\mathrm{xxx})$ indicate averages of similar measurements on 26 lamps, published by Forsythe (12) and his collaborators, showing the good agreement between the two laboratories.

The shaded areas represent the rubescence energy, from which is calculated the erythemogenic efficiency, as illustrated in Table 5 of the preceding paper (3). The slight difference between the values previously published and the new ones given in Table 4 is owing to the adoption of a new spectral erythemic response curve (5), which is considered the most accurate yet determined.

The Uviarc type of quartz mercury arc lamp operates at a high pressure and a high temperature. The type examined is the General Electric 110-volt vertical (Uviarc) lamp operated on 65 volts and about 4 amperes in the burner. Owing to the high current density, the temperature and the pressure are relatively high and the resonance emission line at $254 \mathrm{~m} \mu$ is practically of the same intensity as the lines at 302 and $313 \mathrm{~m} \mu$, in contrast with the so-called "cold quartz" mercury vapor glow lamp (see fig. 3) in which the line at $254 \mathrm{~m} \mu$ contains over 95 per cent of the radiation emitted by these three lines.

As shown in Figure 3, the spectral energy distribution in the radiation emitted by the commercial (vertical type) Uviarc quartz mercury lamp is not markedly different from that of the Mazda S-1 (experimental) lamp in a quartz bulb. Furthermore, the calculated erythemogenic efficiency in the Uviarc lamp (practically new) is only slightly higher than that of the Mazda S-1 lamp in quartz.

The "cold quartz" ultra-violet lamp is essentially a low vapor pressure, low amperage ( 0.015 amperes), high potential (5,000 volts, open circuit), glow discharge, similar to the well-known Geissler tube. The power consumed in the so-called cold quartz mercury vapor lamp is small and consequently there is no great rise in temperature of the burner. 
The spectral energy distribution of this type of ultra-violet lamp is illustrated in Figure 3 . Of the total radiation of all wave lengths less than and including the line at $313 \mathrm{~m} \mu$, over 95 per cent (3) is contained in the resonance emission line of mercury vapor at $254 \mathrm{~m} \mu$. Two models of this type of lamp were examined-a small grid hand lamp in an aluminum reflector and a large hexagonal-shaped grid lamp in a large aluminum reflector, supported upon a stand for body irradiation.

The erythemogenic efficiency of this type of lamp is high (Table 4), but as shown in Figure 3, practically all the erythemal effect is produced by the line at $254 \mathrm{~m} \mu$. The question whether this type of ultra-violet radiation should be used for body irradiation is summarized in another report (13). In a foregoing part of this paper attention is called to the fact that a high erythemogenic efficiency of a source is not necessarily a criterion of its suitability for therapeutic purposes (6).

\section{SPECIFICATION OF MINIMUM INTENSITY AND THE ERYTHEMOGENIC UNIT OF DOSAGE}

In view of the ever-increasing number of ultra-violet radiators that are being placed upon the market, some of which emit practically no radiation of wave lengths shorter than $310 \mathrm{~m} \mu$ (recognized by biologists as having a special therapeutic value) the good agreement between the physiological (erythemal) and the radiometric appraisal of the ultra-violet output of a source finds a direct application in formulating a specification of the amount of ultra-violet that a source must emit in order that it may qualify as a therapeutic agent.

Recently one of the writers (W. W. C.) was called upon by the Council on Physical Therapy of the American Medical Association to obtain information for the purpose of formulating a specification of the amount of ultra-violet radiation that is required for therapeutic purposes.

Based upon a general survey of the problem, involving six distinct summaries of biological and physical data, the conclusion arrived at (2) is that, in order to insure effective therapeutic results, the radiant flux density (intensity) from sources of heterogeneous ultra-violet radiation, of wave lengths less than and including $313 \mathrm{~m} \mu$, evaluated according to the spectral erythemic response curve (as recorded in the foregoing pages) should not be less than the erythemogenic equivalent of $20 \mu \mathrm{w} / \mathrm{cm}^{2}$ of homogeneous radiation of wave lengths of maximum. erythemogenic effectiveness, which wave length, for practical purposes (10), is taken at the emission line of mercury at $297 \mathrm{~m} \mu$ (more exactly $2,967 \mathrm{~A}$ ).

As shown in the preceding pages, the emission line at $297 \mathrm{~m} \mu$ is easily obtainable as a standard source, in sufficient intensity for biological (erythemal) and radiometric tests. Furthermore, the erythemogenic effectiveness of the various sources of heterogeneous radiation, relative to the emission line at $297 \mathrm{~m} \mu$, used as a standard is established with a fair degree of precision by the foregoing radiometric and erythemic tests, which indicate an erythemogenic efficiency of about 15 per cent (estimated) for the Mazda CX tungsten filament lamp; 22 per cent for the sun, etc. (See column 13, of Table 4.) 
From a study of the data available, it was found (2) that a comfortable operating distance is 75 to $90 \mathrm{~cm}$ (2.5 to 3 feet) depending on the source; that for speedy and effective therapeutic results, it is desirable to expose a large area of the nude body (front and back); and that, from a practicable standpoint, the time of a single exposure of any portion of the body should not be continued much longer than 15 minutes. Hence, in formulating a specification, 15 minutes was assumed to be the maximum allowable time of exposure to produce a minimum perceptible erythema on a very sensitive untanned skin.

From the foregoing tests it appears that a 15-minute exposure to a flux density of $20 \mu \mathrm{w} / \mathrm{cm}^{2}$, amounting to a total of $180,000 \mathrm{ergs}$, of wave length $297 \mathrm{~m} \mu$, does not produce an erythema on the average person. If the time of exposure is reduced to 10 minutes, then a radiant flux of $30 \mu \mathrm{w} / \mathrm{cm}^{2}$ of wave length $297 \mathrm{~m} \mu$ would be required in order to obtain 180,000 ergs per $\mathrm{cm}^{2}$.

If the time of exposure is reduced to 1.5 minutes the intensity must be 10 times greater, or $200 \mu \mathrm{w} / \mathrm{cm}^{2}$. As indicated in Table 4, all the sources tested physiologically have a radiant flux of this magnitude at a comfortable operating distance from the lamp.

For the various sources of heterogeneous ultra-violet radiation of wave lengths less than $315 \mathrm{~m} \mu$, the erythemogenic equivalent of 20 $\mu \mathrm{w} / \mathrm{cm}^{2}$ of homogeneous radiation of wave length $297 \mathrm{~m} \mu$ (Table 4) in microwatts per square centimeter, is approximately as follows: The sun $(20 \div 0.22)=91$; (midday, midsummer, midlatitude, sea level); the Mazda S-1 lamp in Corex D bulb, 80; the Mazda S-2 lamp, 93; the high temperature quartz mercury arc, 58; "cold quartz," low pressure, 36 ; carbon ares, 45 to 90 (the latter value is estimated, depending upon the amperage, kind of carbons, kind of window, etc.); and the Mazda CX tungsten filament lamp, 130 $\mu \mathrm{w} / \mathrm{cm}^{2}$ (estimated).

As already mentioned, in addition to the erythemogenic efficiency, other factors must be considered in connection with the use of a lamp for therapeutic purposes. Hence, the choice among lamps can not be based solely on their erythemogenic efficiency.

It is to be emphasized that this specification of a minimum of 20 microwatts per square centimeter of homogeneous radiation of wave length $297 \mathrm{~m} \mu$, or its erythemogenic equivalent of heterogeneous radiation, is the radiant power that is to be applied. The length of time of each exposure, the number of exposures per week, and the total number of exposures (the total energy) required to effect a cure will depend upon the person receiving treatment.

It is important to note that when the sun is used as a source, the intensity can not be increased by decreasing the distance. Hence, it will be necessary to increase the time of exposure. For example, if the ultra-violet intensity (radiant flux density) is only $45 \mu \mathrm{w} / \mathrm{cm}^{2}$, then the exposure must be continued twice as long as for an intensity of $90 \mu \mathrm{w} / \mathrm{cm}^{2}$.

On the other hand, suppose an artificial source of high intensity is being used; for example, a high intensity carbon arc lamp, having an ultra-violet radiant flux of $180 \mu \mathrm{w} / \mathrm{cm}^{2}$ at the standard distance, which is four times the minimum value. It would then be necessary to double the distance in order to reduce the intensity to the standard value, or to reduce the time of exposure to one-fourth the standard value. 
The foregoing discussion leads up to the question of what should be the value of the erythemogenic unit of dosage. As indicated elsewhere (14) the numerical value should be some convenient number, neither too large nor too small.

From the data presented in Table 4 it is to be noted that it requires about $200,000 \mathrm{ergs} / \mathrm{cm}^{2}(200 \mathrm{kiloergs})$ of homogeneous radiation of the wave length of maximum erythemogenic effectiveness to produce a minimum perceptible erythema. The unit of dosage should, therefore, be some lower value in order to guard against overexposure.

It is suggested that $10,000 \mathrm{ergs} / \mathrm{cm}^{2}(10 \mathrm{kiloergs})$ of homogeneous radiation of the wave length $297 \mathrm{~m} \mu$ (15) be adopted as the erythemogenic unit of dosage of ultra-violet radiation and that it be called the Finsen unit (F. U.). Then, according to this specification, the erythemogenic equivalent of heterogeneous ultra-violet radiation, of wave lengths less than and including $313 \mathrm{~m} \mu$, emitted by the abovementioned sources, would be as follows:

$1 \mathrm{~F} . \mathrm{U} .=10,000 \mathrm{ergs} / \mathrm{cm}^{2}$ of the standard wave length, $296.7 \mathrm{~m} \mu$, radiation.

$=45,500 \mathrm{ergs} / \mathrm{cm}^{2}$ of midday, midsummer, midlatitude, sea level solar radiation.

$=40,000 \mathrm{ergs} / \mathrm{cm}^{2}$ of Mazda S-1 lamp radiation.

$=46,500 \mathrm{ergs} / \mathrm{cm}^{2}$ of Mazda S-2 lamp radiation.

$=29,000 \mathrm{ergs} / \mathrm{cm}^{2}$ of quartz mercury arc (uviarc) radiation.

$=18,000 \mathrm{ergs} / \mathrm{cm}^{2}$ of cold quartz radiation.

$=22,500 \mathrm{ergs} / \mathrm{cm}^{2}$ to $45,000 \mathrm{ergs} / \mathrm{cm}^{2}$ of carbon arc lamp radiation. (The larger value depends upon the kind of carbon and whether the arc is bare or is shining through a glass window.)

From the foregoing correlation of the physiologic and radiometric measurements, it will be evident why most of the published data, now available, appear to be inconsistent and misleading. The published measurements do not include a factor that equates the physiological (erythemal) response. As mentioned above, when this factor is taken into consideration, there is good agreement between the observed and computed times of exposure to produce a minimum perceptible erythema, using sources differing very widely in spectral quality and in total intensity of ultra-violet radiation useful for therapeutic purposes.

In conclusion the following illustration is given of the practical application of the Finsen unit. Let us suppose that, from practical experience, it is found that an irradiation of $20 \mathrm{~F}$. U. per day can be given without producing an overexposure, and that a particular Mazda S-2 lamp, having a radiant flux of $100 \mu \mathrm{w} / \mathrm{cm}^{2}$ (1,000 ergs per second) at the standard operating distance, is available for use. Then, from the above described correlations, it follows that $20 \mathrm{~F}$. U. $=930,000$ ergs of Mazda S-2 lamp radiation, and hence, that an exposure of $(930,000 \div 1,000=) 930$ seconds or 15.5 minutes per day is required.

If it requires 100 exposures of Mazda S-2 lamp radiation to effect a cure, this will amount to a total of $2,000 \mathrm{~F}$. U. This seems simpler than to report the total energy in ergs, which in this instance would amount to $93,000,000 \mathrm{ergs} / \mathrm{cm}^{2}$ of Mazda S-2 lamp radiation. 


\section{BIBLIOGRAPHY}

1. Untersuchungen Zur Frage der Dosierung des Ultra-Violetten Lichtes. R. du Mesnil de Rochemont and H. Kirchoff, Strahlentherapie, vol. 41, p. 710, 1931; vol. 43, p. 170 and p. 359, 1932.

2. Ultra-violet Radiation Useful for Therapeutic Purposes; Specification of Minimum Intensity or Radiant Flux, W. W. Coblentz, J. Am. Med. Assoc., vol. 98, p. 1082, March 26, 1932 . Also the Handbook of Physical Therapy, issued by the Council on Physical Therapy of the American Medical Association, 1932.

3. A Balanced Thermcouple and Filter Method of Ultra-Violet Radiometry, with Practical Applications, W. W. Coblentz, R. Stair, and J. M. Hogue, B. S. Jour. Research, vol. 7 (RP370), p. 723, 1931.

4. A New Spectropyrheliometer, W. W. Coblentz and H. Kahler, B. S. Sci. Papers, vol. 16 (SP378), p. 233, 1920. Various modifications of this quartz lens spectrometer have been in use since 1910 (Coblentz, B. S. Bull. (No. 156), vol. 7, p. 245, 1911). As recently used in "An Improved Method of Ultra-Violet Radiometry” (B. S. Tech. News Bull., p. 97, No. 162, October, 1930) the ultra-violet of wave lengths 290 to $313 \mathrm{~m} \mu$ was measured by a photo-electric cell, which was covered with a rectangular slit that transmitted these wave lengths and, similarly, the radiation in this spectral range was measured by a thermopile that was covered with a slit that was cut into a template having the shape of the spectral response curve of the photo-electric cell. In the Trans. Illum. Eng. Soc., vol. 26, p. 305, March, 1931, the filter used was erroneously stated to be "Corex D" instead of barium flint glass.

5. The Spectral Erythemic Reaction of the Untanned Human Skin to UltraViolet Radiation, W. W. Coblentz, R. Stair, and J. M. Hogue, Proc. Nat. Acad. Sci., vol. 17, p. 401, 1931. The complete paper is given in B. S. Jour. Research, vol. 8 (RP433), p. 541, April, 1932.

6. Morton Heilbron and Kamm, J. Chem. Soc., London, vol. 280, p. 2000, 1927. The Biochem, J. vol. 21, p. 78, 1927. Bills, Honeywell, and Cox, J. Biol. Chem., vol. 80, p. 357, 1928. Bourdillon, Fischmann, Jenkins \& Webster, Proc. Roy. Soc., ser. B, vol. 104, p. 561, 1929. According to the Biochem. J., vol. 23, p. 1294, 1929, if wave lengths shorter than 2,750 A are excluded, it is possible to convert approximately 60 per cent of ergosterol into vitamin $\mathrm{D}$, whereas if the source of radiation includes the lines at 2,537 to 2,654 A only a small amount of ergosterol is converted into vitamin D, after which a reaction takes place that destroys the vitamin $\mathrm{D}$ that was created. (Paper by Reerink \& Van Wijk.)

7. Ueber Die Grundlagen Eines Neuen U. V. Messinstrumentes, E. Weyde, Strahlentherapie, vol. 38 , p. 378,1930 . Ultra-Violet Dosimeter, I. G. Farbenindustrie Aktiengesellschaft.

8. An Ultra-Violet Light Meter, H. C. Rentschler, Trans. Illum. Eng. Soc., vol. 25, p. 406, 1930. Trans. Am. Inst. Elect. Eng., New York Convention, January 27 to 31,1930 .

9. Measurements on standards of Radiation in Absolute Value, W. W. Coblentz, B. S. Bull., vol. 11, p. 87, 1914.

10. The question of a suitable method of evaluating an erythemal dose of ultraviolet radiation was discussed independently by J. Saidman and by W. W. Coblentz at the first International Congress on Actinology held in Paris on July 22 to 29,1929 . (Choix d'une Unite de Mesure pour les Rayons Ultra-violets utilisés en Médicine). An abstract report of this meeting, giving mainly the views of Saidman, is published in the Revue d'Optique, vol. 8 , p. 314 , August, 1929 . The complete discussion by Coblentz is published in the Medical J. and Record, vol. 130, p. 691, December 18, 1929. Aside from differences in terminology, and details in practicability, the proposals of these two writers are essentially the same. For example, Saidman proposed the wave length 3,000 A (having an energy value of $10^{6}$ erg) as a basis because of its situation in the solar spectrum. However, since this wave length can not be isolated conveniently in sufficient purity from a continuous spectrum, and since it is not easily obtainable in sufficient intensity in artificial sources, Coblentz suggested the use of the strong emission line of the mercury arc at $2,967 \mathrm{~A}$ (which produces the maximum erythemal effect) and an intensity of 1 or $10 \mu \mathrm{w} / \mathrm{cm}^{2}$. Researches, conducted in the meantime, indicate that the minimum intensity should be not less than $20 \mu \mathrm{w} / \mathrm{cm}^{2}$.- (See reference (2).) 
11. Radiometric Measurements on the Carbon Arc and Other Light Sources Used in Phototherapy, W. W. Coblentz, M. J. Dorcas, and C. W. Hughes, B. S. Sci. Papers, vol. 21 (No. 539) p. 535, 1926.

12. Characteristics of a New Ultra-Violet Lamp, W. E. Forsythe, B. T. Barnes, and M. A. Easley, J. Opt. Soc. Am., vol. 21, p. 34, 1931.

13. Sources of Radiation and Their Physical Characteristics; Cold Red Ray and Cold Ultra-Violet Ray Lamps, W. W. Coblentz, J. Am. Med. Assoc., vol. 97, p. 1965; December 26, 1931 .

14. Instruments for Measuring Ultra-Violet Radiation and the Unit of Dosage in Ultra-Violet Therapy, W. W. Coblentz, Med. J. and Record, vol. 130, p. $691,1929$.

15. Data on Ultra-Violet Solar Radiation and the Solarization of Window Material, W. W. Coblentz and R. Stair, B. S. Jour. Res., vol. 3. (No. 113), p. 629, 1929. The numerical value of the Finsen unit mentioned in this paper ( $\mathrm{p} .643)$ was a rough estimate that had not been subjected to physiological test. The data presented herewith supersede all these earlier estimates.

16. The spectral transmissions of the sample of barium flint glass used in this work may be obtained by subtracting from 0.900 the values given in column 3 of Table 3.

Washington, April 22, 1932. 